\title{
Biophysical controls on seasonal changes in the structure, growth, and grazing of the size-fractioned phytoplankton community in the northern South China Sea
}

5 Yuan Dong ${ }^{1,2}$, Qian P. Li ${ }^{1,2,3 *}$, Zhengchao $\mathrm{Wu}^{1,2}$, Yiping Shuai ${ }^{1,3}$, Zijia Liu ${ }^{1,3}$, Zaiming Ge ${ }^{1,3}$, Weiwen Zhou ${ }^{1,3}$, and Yinchao Chen ${ }^{1,3}$

${ }^{1}$ State key Laboratory of Tropical Oceanography, South China Sea Institute of Oceanology, Chinese Academy of Sciences, Guangzhou, China

$10 \quad{ }^{2}$ Southern Marine Science and Engineering Guangdong Laboratory (Guangzhou), Guangzhou, China

${ }^{3}$ College of Marine Science, University of the Chinese Academy of Sciences, Beijing, China

*Correspondence to: Qian P. Li (qianli@scsio.ac.cn)

Abstract. The size-fractionated phytoplankton growth and microzooplankton grazing are crucial for the temporal change of community size-structure, regulating not only trophic transfer but also carbon cycle of the ocean. However, the size-dependent growth and grazing dynamics on monthly or an annual basis are less addressed in the coastal ocean. In this paper, the seasonal responses of the size-fractionated phytoplankton growth and grazing to environmental change were examined over a one-year period at a coastal site of the northern South China Sea. We found a nanophytoplankton dominated community with strong seasonal variations of all size classes. Phytoplankton community growth rate was positively correlated to nutrients with community grazing rate correlating to the total chlorophyll- $a$ at the station, reflecting a combined bottom-up and top-down effect on phytoplankton population dynamics. Further analyses suggested that the specific growth rate of microphytoplankton was significantly influenced by phosphate with that of nanophytoplankton by light, although picophytoplankton growth was controlled by both nitrate and temperature. In addition, the specific grazing rate of nanophytoplankton was well correlated to phytoplankton standing stock, while those of micro- and picocompartments were negatively influenced by ciliate abundance and salinity. Finally, a lower grazing impact for micro-cells (38\%) than nano- and pico-cells ( $72 \%$ and $60 \%$, respectively) may support a size-selective grazing of microzooplankton on small cells at this eutrophic system. 
https://doi.org/10.5194/bg-2021-226

Preprint. Discussion started: 1 September 2021

(c) Author(s) 2021. CC BY 4.0 License.

\section{Introduction}

Plankton are the basic components of the aquatic food web. Phytoplankton net growth can be influenced by nutrient availability (such as nitrogen, phosphorus, silica, or iron) via the bottom-up effect and/or zooplankton grazing via the topdown effect (Strom et al., 2007). Grazing of bacterioplankton by microzooplankton (such as nanoflagellates and ciliates) has been well-known in aquatic environments (Ichinotsuka et al., 2006; Unrein et al., 2007; Schmoker et al., 2013). Microzooplankton are generally the dominant herbivores in the marine ecosystem (Calbet and Landry, 2004), regulating not only primary productivity but also the cycling of carbon and nutrients in the ocean (Steinberg and Landry, 2017). Spatial changes of phytoplankton growth and microzooplankton grazing have been well appreciated in the coastal ecosystems due to rapidly varying environmental conditions such as temperature, nutrients, and light (e.g. Landry et al., 2009; Li et al., 2012; Dong et al., 2018). In contrast, temporal variabilities in rate processes over an annual cycle or on a monthly basis are often less addressed, not to mention the relevant controlling mechanisms (Calbet et al., 2008; Chen et al., 2009; Anderson and Harvey, 2019). This aspect of temporal dynamics, however, may be essential for understanding the long-term change of biological productivity, community structure, and ecosystem functions in the coastal oceans.

The coastal regions of the northern South China Sea (NSCS) are subject to strong influences by complex physical processes, such as wind-induced mixing, coastal upwelling, river discharge, and atmospheric deposition. Seasonal variation of primary productivity over the NSCS shelf could be related to hydrographic dynamics driven by varying monsoon winds with a stronger turbulent mixing during the winter (e.g. Liu et al., 2002). Furthermore, nutrient concentration and stoichiometry of the surface waters could be influenced by the interplay between river discharge (a high N/P ratio) and coastal upwelling (a low N/P ratio) over the inner shelf of the NSCS (Gan et al., 2010), leading to intense phytoplankton blooms during the summer. In addition, the river plume would affect the size-structure of the phytoplankton community with large-sized phytoplankton such as diatoms well promoted at the frontal zone ( $\mathrm{Li}$ et al., 2018). Finally, recent studies suggested that atmospheric depositions of nutrients and toxic metals could also largely affect coastal phytoplankton growth and the community compositions of the nearshore waters in the NSCS (Zhou et al., 2021).

The Pearl River Estuary (PRE), with an area of about $4.5 \times 10^{5} \mathrm{~km}^{2}$, is one of the largest river systems in the northern South China Sea (NSCS). Wanshan archipelago, located at the mouth of the PRE, is the primary channel for the Pearl River waters entering the shelf-sea. Therefore, the surrounding waters near Wanshan often showed a rapid change of salinity and nutrients due to the interplay between the estuarine freshwater and the adjacent coastal seawater. Similar to many other estuarine-coastal ecosystems around the world (Clerm et al., 2014), there is high production at the estuary mouth near the Wanshan region but low production in the turbidity maximum zone within the estuary. Previous studies have suggested that intense diatom blooms could occur in the coastal waters near Wanshan during the summer in response to strong eutrophication (e.g. Li et al., 2013). Further studies suggested that phytoplankton growth in this land-sea interface could be influenced by several processes, including nutrient limitation (Li et al., 2018), size-fractionated microzooplankton grazing 
https://doi.org/10.5194/bg-2021-226

Preprint. Discussion started: 1 September 2021

(c) Author(s) 2021. CC BY 4.0 License.

(c) (i)

(Dong et al., 2018), and the deterrent effect of phytoplankton-derived oxylipins on zooplankton grazers (Wu and $\mathrm{Li}, 2016$ ). Meanwhile, it remains largely unknown about the seasonal patterns of phytoplankton productivity and the grazing activity of microzooplankton in the coastal waters outside the highly euphotic estuary.

In this study, we focus on a coastal time-series station near the Wanshan to explore the temporal change of the plankton ecosystem from June 2018 to June 2019. We have performed comprehensive measurements of the plankton community, including the chlorophyll-a size-fractionation, the picophytoplankton composition by flow cytometry, the nano- and microplankton abundances by FlowCAM, and the size-fractionated growth and grazing rates by dilution experiments, in addition to regular hydrological and biogeochemical measurements. Based on these data, we investigate the monthly variabilities of phytoplankton size-structure and size-fractionated growth rates at the Wanshan station. We explore the underlying relationships of these variabilities with changing environmental conditions such as temperature, light, and nutrients. We also examine the monthly patterns of major microzooplankton abundances and the size-dependent grazing rates to address the trophic interaction of microzooplankton with their phytoplankton prey. The goal is to improve our understanding of plankton dynamics in this highly eutrophic system. We believe these results should be critical for future plankton ecosystem modeling and for predicting shifts in plankton population dynamics and food web processes within coastal marine ecosystems in response to climate change.

\section{Materials and Methods}

\subsection{Description of the field study and measurement of environmental parameters}

We also conducted monthly hydrographic and biogeochemical monitoring, as well as phytoplankton chlorophyll- $a$ sizefractionation and size-specific dilution experiments at the Wanshan station (Fig. 1) from June 2018 to June 2019. This station $\left(21.9^{\circ} \mathrm{N}, 113.8^{\circ} \mathrm{E}\right)$ is located near the Wanshan Island of the NSCS with a water depth of $\sim 28 \mathrm{~m}$ (see Fig. 1). Water temperature and salinity were measured using a pre-calibrated YSI multi-probe sensor. Surface waters at $\sim 2 \mathrm{~m}$ (about $100 \mathrm{~L}$ ) were directly collected with an acid-cleaned polycarbonate bucket. After removing the larger grazers $(>200 \mu \mathrm{m})$ using a 200$\mu \mathrm{m}$ mesh, water samples were gentle transferred to polycarbonate bags in a temperature-controlled cooler in the dark.

The sample for inorganic nutrients, including nitrate $\left(\mathrm{NO}_{3}{ }^{-}\right)$, phosphate $\left(\mathrm{PO}_{4}{ }^{3-}\right)$, and silicate $\left(\mathrm{SiO}_{3}{ }^{2-}\right)$, was pre-filtered through a $\mathrm{GF} / \mathrm{F}$ filter and frozen immediately at $-20^{\circ} \mathrm{C}$ in a freezer. Samples were thawed at room temperature and measured by a Seal AA3 auto-analyzer (Bran-Luebbe, $\mathrm{GmbH}$ ) using the classic colorimetric methods (Hansen and Koroleff, 1999). The monthly solar radiation data was acquired from a nearby weather station in Hong Kong City (https://www.hko.gov.hk).

There were three major subbranches of the Pearl River system (West, North, and East rivers), flowing into the shelf-sea through eight different outlets. The total flow rate to the Wanshan station was estimated by the sum of three major entrances at Humen, Modaomen, and Jiaomen (Guangdong Hydrographic Bureau, http://swj.gd.gov.cn/zwgk_tjxx/index.html). 
https://doi.org/10.5194/bg-2021-226

Preprint. Discussion started: 1 September 2021

(c) Author(s) 2021. CC BY 4.0 License.

(c) (i)

To show the typical difference in the hydrographic characters of the coastal NSCS between winter and summer, sectional data of two cruises crossing the Wanshan station during December 2006 and June 2019 were used (Fig. S1). The vertical transects covered the major river-influenced area from the estuary to the inner shelf of the NSCS. The profiles of seawater temperature, salinity, and pressure were continuously measured using a Sea-Bird model SBE9/11 conductivitytemperature-depth (CTD) sensor.

\subsection{Phytoplankton and zooplankton measurements}

After returned to the laboratory, the Chl- $a$ size-fractionation for micro- $(20-200 \mu \mathrm{m})$, nano- $(2-20 \mu \mathrm{m})$, and picophytoplankton $(<2 \mu \mathrm{m})$ (Dong et al., 2018) were performed immediately. Duplicated seawater samples $(1 \sim 2 \mathrm{~L})$ were processed through a sequence of filtration steps under a low vacuum $(<50 \mathrm{kPa})$, including a $20-\mu \mathrm{m}$ pore size Nylon membrane filter, a $2-\mu \mathrm{m}$ pore size polycarbonate filter, and a GF/F filter. Total Chl- $a$ was calculated as the sum of the Chl- $a$ concentrations of the three different size classes. The filters were extracted in $90 \%$ acetone for at least $18 \mathrm{~h}$ in the dark at $-20^{\circ} \mathrm{C}$. After centrifuged at $4000 \mathrm{rpm}$ for $10 \mathrm{~min}$, the Chl- $a$ concentration was determined by a Turner Designs Model 10 105 Fluorometer (Parsons et al., 1984).

For picoplankton, a volume of 2-mL seawater sample was pre-filtered by a $38 \mu \mathrm{m}$ filter and fixed by paraformaldehyde ( $0.5 \%$ final concentration). After 10 -min of reaction, the samples were frozen and stored at $-80{ }^{\circ} \mathrm{C}$. Abundances of Synechococcus, picoeukaryotes, and Prochlorococcus-like cells were enumerated using Beckman Coulter's CytoFLEX S Flow Cytometer (Zhou et al., 2020). Carbon biomasses of Synechococcus, picoeukaryotes, and Prochlorococcus-like cells

110 were estimated using the converting factors of 101, 530, and $32 \mathrm{fg} \mathrm{C}$ cell L ${ }^{-1}$, respectively (Garrison et al., 2000; Worden et al., 2004). Samples were prepared in triplicate.

We measured the abundances of ciliates and chain-forming diatom via an automated FlowCAM system (Portable Series FlowCAM). Dinoflagellates are also important at the Wanshan station but difficult to be accurately quantified by FlowCAM. The samples were screened by a $200 \mu \mathrm{m}$ mesh to remove large particles. A volume of $300 \mathrm{~mL}$ sample was analyzed on 115 Auto-image mode using a 300- $\mu \mathrm{m}$ flow cell and a flow rate of $2 \mathrm{ml} \mathrm{min}{ }^{-1}$ (Anderson and Harvey, 2019; Haraguchi et al., 2018). Duplicate runs were pooled for each experiment. The results of FlowCAM were further validated by the inverted microscopic method. Briefly, seawater of $1000 \mathrm{ml}$ was fixed with acidic Lugol's solution (1\% final concentration) and stored in amber plastic bottles at room temperature. After pre-concentrated using the Utermöhl method (Utermöhl, 1958), a $20 \mathrm{ml}$ subsample was counted with an inverted microscope at $200 \times$ magnification.

\subsection{Setup of size-specific multi-treatment dilution experiments}


The size-specific dilution experiment was carried out directly at a coastal pier near the sampling site. The protocol of dilution experiments has been described in detail by Dong et al. (2018). Briefly, all the bottles, tubing, and carboys for the dilution experiment were soaked in $10 \% \mathrm{HCl}$ for at least $24 \mathrm{~h}$, rinsed with deionized water and in situ surface seawater successively before each experiment. Particle-free water was prepared by gravity filtered the prescreened seawater through a $0.2 \mu \mathrm{m}$ filter. The whole seawater was gently poured into $2.4 \mathrm{~L}$ polycarbonate bottles containing specific volumes of particle-free water to obtain a dilution series of $10 \%, 20 \%, 40 \%, 70 \%$, and $100 \%$ whole seawater. Each dilution treatment was duplicated during the experiment. Ten incubation bottles were enriched with dissolved inorganic nutrients of $5 \mu \mathrm{mol}^{-1}$ $\mathrm{NaNO}_{3}, 0.5 \mu \mathrm{mol} \mathrm{l}^{-1} \mathrm{KH}_{2} \mathrm{PO}_{4}$, and $5 \mu \mathrm{mol} \mathrm{l}^{-1} \mathrm{Na}_{2} \mathrm{SiO}_{3}$ to ensure the constant growth of phytoplankton (particularly to avoid nutrient limitation during winter). The amounts of nutrients are slightly lower than those used by Chen et al. (2009), given that our Wanshan station is relatively closer to the northern South China Sea than their site. There were two additional bottles filled with the whole seawater served as controls without nutrient addition. All these bottles were tightly capped and incubated for $24 \mathrm{~h}$ in an incubator filled with the running surface seawater and covered with a neutral density screen to mimic the in situ temperature and light at the station. Initial Chl- $a$ concentrations of the diluted bottles were estimated from the whole seawater multiplied by the dilution factor. Aliquots of $500 \mathrm{ml}$ samples at the end of the $24 \mathrm{~h}$ culture were taken from each bottle for Chl- $a$ measurement.

\subsection{Estimates of growth rate and grazing rate}

Estimates of nutrient-saturated phytoplankton growth rates $\left(\mu_{n}, \mathrm{~d}^{-1}\right)$ and microzooplankton grazing rates $\left(m, \mathrm{~d}^{-1}\right)$ for each phytoplankton size-class (Landry and Hassett, 1982) were calculated with least-square regression between the apparent growth rates $\left(\varepsilon, \mathrm{d}^{-1}\right)$ and the dilution factors $(D)$ as

$$
\varepsilon_{i}=\frac{1}{t} \ln \left[\frac{C h l_{i}(t)}{C h l_{i}(0)}\right]=\mu_{n_{i}}-D \cdot m_{i}
$$

where $C h l_{i}(0)$ and $C h l_{i}(t)$ are the initial and final concentrations of Chl- $a$ for each phytoplankton size-class $i$ (micro, nano-, and pico-phytoplankton, respectively); $\varepsilon_{i}, \mu_{n i}$, and $m_{i}$ are the size-specific rates for the size-class $i$ with $t$ the incubation time 145 (one day in our experiment). The intrinsic growth rate $\left(\mu_{0}\right)$ is calculated as the sum of the net growth rate without nutrient enrichment ( $\left.\varepsilon_{\text {raw }}\right)$ and the grazing rate (Landry et al., 1993).

\subsection{Statistics Analysis}

Statistical analyses were performed using software SPSS 14.0. Comparisons between environmental variables were 
permutation test was carried out to determine the significance of the slopes and calculate the $p$-value. The level of $p<0.05$ was considered significant, with $p<0.01$ as strong significance. Following the One way independent measures ANOVA (oneway ANOVA), the significance of the difference between growth/grazing rates and zero was checked using Tukey's HSD test. Responses of the size-fractionated growth and grazing rates to varying environmental parameters were investigated by multivariate statistical analyses using CANOCO version 5.0. Redundancy analysis (RDA) was used to summarize relations between size-fractionated rates and environmental parameters once the length of the first gradient was satisfied by a linear justification.

\section{Results}

\subsection{Temporal change of hydrodynamics in the study area}

At the Wanshan station, there was a strong stratification induced by river discharge and seawater intrusion during the summer in contrast to the well mixed water column during the winter (Fig S1). Despite a much higher seawater temperature, surface salinity was much lower in the summer (15.3 \pm 8.1$)$ than in the winter (33.3 \pm 0.2$)$, reflecting a stronger river discharge. The structure of the summer river plume was manifested by a layer of low salinity (7.2-24.4) surface water extending from the estuary to the inner shelf

Pronounced seasonal variations in temperature, salinity, river flow, and solar radiation were observed during the oneyear time-series study at the Wanshan station (Fig. 2A and 2B). The annually averaged temperature is about $24.8 \pm 3.5^{\circ} \mathrm{C}$, varying from 19.0 to $28.5^{\circ} \mathrm{C}$ (Fig. 2A). Salinity fluctuation at Wanshan was evidenced in response to the seasonal flood of freshwater runoff from the Pearl River. While a substantially low salinity $(<26)$ showed up in June, August, and September 2018 , there was a relatively higher salinity of $\sim 33$ found during the other months of the year. There was about $66 \%$ of the river discharge occurring in the wet season of April-September with a total flow rate of $82.7 \times 10^{3} \mathrm{~m}^{3} \mathrm{~s}^{-1}$, which is about twice that in the dry season of October-March (total of $41.5 \times 10^{3} \mathrm{~m}^{3} \mathrm{~s}^{-1}$ ) (Fig. 2B).

A strong negative correlation between the monthly flow rate of the Pearl River and the salinity at Wanshan $(r=-0.82$, $n=12, p<0.01$ ) was observed, which should indicate an essential role of river input on the temporal change of local hydrodynamics at the Wanshan station. Also, the flow rate was positively correlated with nitrate and silicate concentrations (Table S1), which may reflect a major source of nutrients to the Wanshan station from river discharge. There was an

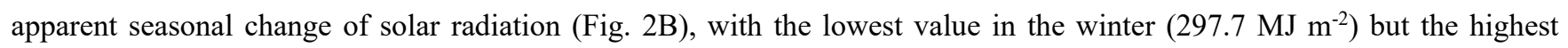
value in the summer $\left(546.2 \mathrm{MJ} \mathrm{m}^{-2}\right)$. We also found periods of slightly reduced light intensity during August and May due to the cloud coverage. Solar radiation was positively correlated to temperature throughout the year $(r=0.76, n=12, p<0.01)$ but not with any other environmental parameters at our station (Table S1). 
https://doi.org/10.5194/bg-2021-226

Preprint. Discussion started: 1 September 2021

(c) Author(s) 2021. CC BY 4.0 License.

\section{(c) (1)}

\subsection{Temporal change of plankton ecosystem and biogeochemistry}

Surface concentrations of nitrate ranged from 3.6 to $69.4 \mu \mathrm{mol} \mathrm{L}^{-1}$ (with an average of $25.3 \pm 23.7 \mu \mathrm{mol} \mathrm{L}^{-1}$ ) (Fig. 2C). There were peaks of nitrate in June, September, January, and April during the one-year cycle, with the highest concentration of $64.8 \mu \mathrm{mol} \mathrm{L}{ }^{-1}$ found in September. Nitrate concentration decreased dramatically in the late autumn, with the lowest 3.6 $\mu \mathrm{mol} \mathrm{L}{ }^{-1}$ found in December. Temporal variations of phosphate and silicate were generally in agreement with that of nitrate (Fig. 2C), which was confirmed by significant correlations between nitrate and phosphate $(r=0.64, n=12, p<0.05)$ and between phosphate and silicate $(r=0.73, n=12, p<0.01)$. The surface N/P ratios were very high at the Wanshan station (21.6116.4), indicating a potential phosphorus deficiency compared to the Redfield ratio. Salinity showed strong negative correlations with both nitrate and silicate, which should reflect the impact of river discharge with an intense mixing between the eutrophic river water and the low-nutrient seawater at the Wanshan station. Interestingly, phosphate was not well correlated with salinity (Table S1), which may indicate an extra utilization of P compared to other nutrients. Likely, an increased $\mathrm{P}$ consumption could occur here given the phosphorus deficiency driven by very high N/P ratios.

There was a large seasonal change of total Chl- $a$ varying from 0.33 to $8.1 \mu \mathrm{g} \mathrm{L}^{-1}$ during the study period (with an average of $1.9 \pm 2.2 \mu \mathrm{g} \mathrm{L}^{-1}$ ). Consistent with those of nutrients, a generally higher total Chl- $a$ was found during the summer with a maximum of $8.1 \mu \mathrm{g} \mathrm{L}^{-1}$ in August. In contrast, a low Chl- $a$ concentration of $1.0 \pm 0.3 \mu \mathrm{g} \mathrm{L}^{-1}$ was found among the other months of the year. For the size-fractioned Chl- $a$, the phytoplankton community was predominated by nano-cells (on average $60.4 \pm 14.5 \%)$ throughout the year, followed by pico- $(22.4 \pm 7.5 \%)$ and micro-cells (17.2 $14.5 \%)$, respectively. Also, there was a high Chl- $a$ concentration and a high percentage of microphytoplankton showing up in June and August 2018 (Fig. 3A) when the total Chl-a concentration was high (Fig. 3B). A high percentage of micro-cells was also found in February and May 2019, although the total Chl- $a$ was relatively low (Fig. 3B).

The abundance of diatom, dominant by chain-forming taxa (mainly Skeletonema costatum and Staphylococcus spiralis), varies substantially from undetectable to $23.8 \times 10^{5}$ cell $\mathrm{L}^{-1}$ during our study period (Fig. 4A). A seasonal change of diatom abundance was documented with a lower concentration in the winter but a high concentration in the summer. Consistent with that of the pico-sized Chl- $a$ (Fig. 3A), there was a much higher picophytoplankton carbon biomass found in the summer than in the winter (Fig. 4B). Generally, Synechococcus dominated the picophytoplankton community most of the year, with an average abundance of $30.4 \pm 26.7 \times 10^{6}$ cells $\mathrm{L}^{-1}$. Prochlorococcus-like cells were mostly negligible through the one year study (Fig. 4B) except for some months during the summer with high nutrients but low salinity (Fig. 2B and 2C). Microzooplankton at the Wanshan station were dominated by ciliates (mostly aloricate ciliates and Tintinnids; similar to 210 Chen et al., 2009). There was a seasonal change of ciliates (Fig. 4C) with a higher abundance found in July (1220 ind L $\left.{ }^{-1}\right)$ and October (540 ind $\left.\mathrm{L}^{-1}\right)$.

\subsection{Temporal change of phytoplankton growth and microzooplankton grazing rates}


https://doi.org/10.5194/bg-2021-226

Preprint. Discussion started: 1 September 2021

(c) Author(s) 2021. CC BY 4.0 License.

\section{(c) (i)}

Figure S2 are the typical results of the size-specific dilution experiments (only two representative months are shown due to the space limitation). Generally, a significantly linear relationship between apparent growth rate and the dilution factors was acquired during our monthly dilution experiments. However, the dilution method could not apply to the experimental results of July and October 2018 when a positive slope of the dilution curve was found together with a very high ratio of ciliates over the total Chl-a (Fig. 4C). The natural growth rates during these two months could be estimated from the undiluted treatment assuming a zero grazing rate as suggested by Calbet and Saiz (2013) when a trophic cascade occurring in the dilution experiment due to omnivorous ciliates feeding on smaller carnivores.

Results of all the monthly dilution experiments at the Wanshan station are shown in Fig. 5 and Table S2. There were apparent seasonal differences in both growth and grazing rates during our observation period. Generally, we found higher rates in summer than spring/winter for both phytoplankton growth and microzooplankton grazing. Phytoplankton growth rate $\left(\mu_{0}\right)$ varied from -0.34 to $2.96 \mathrm{~d}^{-1}$ with an average of $1.09 \pm 0.95 \mathrm{~d}^{-1}$ during the one-year cycle (Fig. $\left.5 \mathrm{~A}\right)$. The negative rate of $0.34 \mathrm{~d}^{-1}$ was found in the February with the lowest temperature and solar radiation, which however was barely different from zero (One-Way ANOVA, $p=0.24$ ). Temporal change of grazing rate $(m)$ was much different from that of growth rate, with the highest rate of $\sim 2.1 \mathrm{~d}^{-1}$ showing up in August (Fig. 5B). These were apparent decoupling between phytoplankton growth and microzooplankton grazing in August and September 2018.

Temporal variations of the size-fractioned growth and grazing rates generally followed the trends of total community

with higher rates in the summer but lower rates in the winter/spring. There was no general difference found among the natural growth rates of three phytoplankton size classes $(p>0.05)$ except April and May 2019. An elevated growth of microcells but a reduced growth of nano-cells was found in April 2019 compared to that of pico-cells (Fig. 5A). Also, there were large negative intrinsic growth rates of nanophytoplankton during April and May 2019 (significant different from zero, OneWay ANOVA, $p<0.01$ ), further discussed in the next section. There was an increase of microzooplankton grazing on picocells in September 2018 and June 2019 but on large cells in November and February 2018 (Fig. 5B). For the nutrientenriched growth rate (Fig. 5C), there were substantial increases in growth rate $\left(\mu_{\mathrm{n}}\right)$ found in June, September, January, and April, which was well consistent with the elevated nutrient concentrations in these months shown previously (Fig. 2C). Generally, the annual average of the nutrient-enriched growth rate $\left(1.68 \mathrm{~d}^{-1}\right)$ was higher than that of the natural growth rate $\left(1.22 \mathrm{~d}^{-1}\right)$, indicating a nutrient limitation of phytoplankton even in this highly eutrophic system.

\section{Discussion}

\subsection{What controls the seasonal change of phytoplankton production?}

Phytoplankton growth in the ocean can be influenced by several factors, such as temperature, light, nutrients, and community structure (e.g. Li et al., 2010). Temperature has been known as an important driver for phytoplankton growth (e.g. 245 Eppley, 1972). The temperature effect on phytoplankton growth at the Wanshan station was evidenced by a strong 
https://doi.org/10.5194/bg-2021-226

Preprint. Discussion started: 1 September 2021

(c) Author(s) 2021. CC BY 4.0 License.

\section{(c) $\underset{\mathrm{BY}}{\mathrm{BV}}$}

correlation of the community growth rate with the temperature $(r=0.96, n=6, p<0.01)$ during the period of October to April when the nutrient concentration was relatively constant. The effect of light on phytoplankton growth at the Wanshan station was similar to that of temperature given the strong correlation between solar radiation and temperature.

Besides temperature and light, dissolved nutrients can also affect phytoplankton growth at the Wanshan station. During June-September 2018 when the water temperature was relatively constant, the community growth rate showed strong correlations with nutrients $(r=0.95, n=4, p<0.01$ for nitrate) but not with other parameters, such as light and grazing. However, the mean nutrient limitation index of $\mu_{0} / \mu_{\mathrm{n}}$ for the whole community was about $0.9 \pm 0.2$ at the Wanshan station, suggesting that phytoplankton here was generally not limited by nutrients. This could well explain the very similar patterns found between the nutrient-enrich growth rates $\left(\mu_{\mathrm{n}}\right)$ and the natural growth rate $\left(\mu_{0}\right)$ for total phytoplankton community. A negative correlation of the growth rate with salinity during the one-year cycle could be attributed to nutrients given the tight relationship between salinity and nutrients at the Wanshan station. Actually, we can simply divide the environmental variables into two independent groups based on their correlations with each other (Table S1), including temperature (light) and nutrient (salinity). The slow growth of phytoplankton community (together with a low Chl-a level of $<1 \mu \mathrm{g} \mathrm{L}^{-1}$ ) in the winter was consistent with the low temperature and the low nutrient conditions. Thus, the interplay between the two groups of independent factors may be responsible for the seasonal change of phytoplankton growth during the one-year period.

It is surprising to find negative intrinsic growth rates of nanophytoplankton during April and May 2019. The natural growth of nanophytoplankton was likely limited by nutrients since its growth was well promoted during the nutrientenriched treatments (Fig. 5C). Moreover, a substantially high N/P ratio during these two months suggested that phosphate was largely deficient relative to nitrate in these waters. Phosphorus limitation of nanophytoplankton may infer a disadvantage of nano-cells in competing for phosphorus resource with micro- and pico-cells. Recent studies suggested that picophytoplankton could store and liberate poly-phosphate to support high productivity in a low phosphate environment ( $\mathrm{Li}$ et al., 2019). Also, it has been well-known that microphytoplankton could use dissolved organic phosphorus to sustain growth and maintain a sufficient amount of biomass under P deplete conditions (Girault et al., 2013). However, nanophytoplankton by itself tends to be limited by phosphorus compared to other size phytoplankton when a high N/P ratio was observed. Therefore, a substantial difference in growth rate among the three size classes during April 2019 should reflect their different tolerance capacity to P-deficiency.

To explore the controlling factors for the size-fractionated growths of phytoplankton over the annual cycle, we applied the Redundancy analyses (RDA) to the data of growth rates and environmental variables (Fig. 6A). The first axis explains $\sim 69.63 \%$ of the variance in growth rate with the second axis for $\sim 13.1 \%$, which should guarantee the validation of the RDA method in our study area. The statistical approach highlighted several important factors in driving the observed seasonal change in the size-fractionated phytoplankton growth rates, including temperature, light, and nutrients (Fig. 6A). Microphytoplankton growth seemed more influenced by phosphate than by other factors. This is consistent with the phosphorus control of large phytoplankton growth commonly found in the frontal zones near Wanshan (Li et al., 2018). A higher maximal growth rate together with a larger half-saturation constant will be an advantage for microphytoplankton 
https://doi.org/10.5194/bg-2021-226

Preprint. Discussion started: 1 September 2021

(c) Author(s) 2021. CC BY 4.0 License.

\section{(c) (1)}

growth (Dong et al., 2018) in response to increase of P loading from river inputs in a P-deficient system with extremely high $\mathrm{N} / \mathrm{P}$ ratios. In contrast, picophytoplankton growth was primarily controlled by nitrate and temperature. This finding is also in good agreement with the previous reports that the growth rates of Synechococcus and picoeukaryotes would generally increase with temperature and nitrate concentrations in the coastal NSCS (Chen et al., 2014). Interestingly, we found nanophytoplankton was more controlled by light than the other factors. The dominant species of nanophytoplankton in the PRE region are small chain-forming diatoms, such as S. costatum and Thalassiosira spp, with chain lengths (or diameters of cell colonies) of less than $20 \mu \mathrm{m}$ ( $\mathrm{Li}$ et al., 2013). These small-sized chain-forming diatoms (nanophytoplankton) can grow first when light limitation is relieved in the eutrophic environment and followed by larger species as nutrients are consumed (e.g. Guillard and Kilham, 1977).

\subsection{Drivers for seasonal variability in microzooplankton grazing}

Generally, microzooplankton grazing at the Wanshan station varied substantially on an annual cycle in response to change in phytoplankton concentration and composition. It is surprising that we find a zero grazing rate in July when the temperature is high, despite of a positive correlation between community grazing rate and temperature $(r=0.62, n=12$, $p<0.05)$. In addition, extensive modulation of grazing rate was observed during June-September 2018, when the water temperature was mostly constant. The temperature effect on microzooplankton grazing may not be straightforward (Rose and Caron, 2007). It should be pointed out that the temperature sensitivity of microzooplankton grazing could have been masked in our monthly data given the large fluctuation of grazing rate over a wide range of Chl-a levels. Though other environmental factors such as light and nutrients may likely be relevant to grazing rates in the coastal ocean (Chen et al., 2009), these relationships were not supported by our direct linear regression analyses at the Wanshan station (Table S1).

Our results support the density-dependent prey ingestion kinetics found in laboratory culture experiments (e.g. Holling, 1959), as evidenced by a significant correlation of the community grazing rate with the total phytoplankton Chl- $a$ concentration $(r=0.82, n=12, p<0.01)$. Based on the classic Holling II grazing model, a positive correlation between microzooplankton grazing rate and phytoplankton standing stock may occur during non-saturated feeding (Dong et al., 2018). However, size-dependent selectivity of microzooplankton grazers on phytoplankton prey can affect the community grazing activity resulting in decoupling between resident grazers and preys (Poulin and Franks, 2010). In this case, grazer biomass alone may not accurately reflect community grazing rates (Menden-Deuer et al., 2018). This was likely the case at the Wanshan station when the community grazing rate was poorly explained by the ciliate abundance. Meanwhile, our observation of a reverse correlation between diatom and ciliate abundances during the summer might partly support the previous hypothesis of a chemical defense of diatoms to microzooplankton grazing (Wu and Li, 2016; Franzè et al., 2018).

Redundancy analyses were also employed to address the linkages between the size-fractionated grazing rates and the environmental variables (Fig. $6 \mathrm{~B}$ ), with the first axis accounting for $\sim 69.4 \%$ and the second axis for $\sim 12.8 \%$ of the variance. 
https://doi.org/10.5194/bg-2021-226

Preprint. Discussion started: 1 September 2021

(c) Author(s) 2021. CC BY 4.0 License.

\section{(c) (i)}

The grazing mortality rate of nano-cells was more correlated to the size-fractionated Chl- $a$ concentrations and picoplankton biomass than the other factors. This result is consistent with the significant correlation between community grazing rate and total Chl- $a$ mentioned in the previous paragraph since nano-phytoplankton was the dominant size-class at the Wanshan station. Interestingly, the grazing rate on micro-cells was negatively influenced by the ciliate abundance. A reverse correlation of ciliate with the grazing rate could likely be explained by trophic cascade with the feeding of omnivorous ciliates on other microzooplankton reducing the overall grazing pressure on phytoplankton (Zollner et al., 2009). Of course, without the data of smaller microzooplankton such as dinoflagellates, we cannot completely rule out other possibilities. Finally, we found a negative correlation of salinity with the grazing rate on picophytoplankton. It has been suggested that small herbivores, such as heterotrophic nano-flagellates, would preferentially graze on picoplankton (Christaki et al., 2001), although they are more sensitive to salinity change in mesotrophic coastal waters (Jolliff et al., 2012). The negative effect of salinity on smaller zooplankton in the Jiaozhou Bay of the South Yellow Sea has been attributed to stimulated phytoplankton growth by the input of high-nutrient freshwater (Wang et al., 2020). This may likely be also true at the Wanshan station given the tight correlation between salinity and nutrients.

We found that microzooplankton grazing was an important pathway for phytoplankton loss in coastal waters outside the PRE, although there was a large difference among the three size classes (Fig. 7). On average, microzooplankton consumed $\sim 38 \%$ of microphytoplankton production $(r=0.62, n=21, p<0.01$ ), much lower than that of $\sim 72 \%$ for nanophytoplankton $(r=0.63, n=15, p<0.01)$ and $\sim 60 \%$ for picophytoplankton $(r=0.75, n=17, p<0.01)$ (Fig. 7$)$. Our values for nano- and picophytoplankton are consistent with those of $60-75 \%$ reported in the global ocean (Calbet and Landry, 2004). The low grazing impact for microphytoplankton may suggested that additional processes not captured by the dilution technique, such as mesozooplankton grazing, might also be important for the loss of primary production near Wanshan.

Mesozooplankton $(>200 \mu \mathrm{m}$ ) would prefer grazing on large-sized phytoplankton (such as dinoflagellates and diatoms) but typically account for less consumption of primary production compared to microzooplankton (Steinberg and Landry, 2017). Field studies near the PRE had suggested that the contribution of mesozooplankton grazing to the loss of primary production could vary substantially from $0.7 \%$ to $31 \%$ (Chen et al., 2015).

A lower grazing impact on microphytoplankton compared to the other two size classes may imply size-selective grazing of microzooplankton on small cells near Wanshan of the PRE. This result is contradicted to the previous finding of no sizeselective grazing of microzooplankton on phytoplankton in the coastal waters west of Hong Kong (Lie and Wong, 2010). Meanwhile, it is consistent with our finding of high abundance of large chain-forming diatoms in microphytoplankton at the Wanshan station, which can effectively avoid grazing by microzooplankton and copepod due to their chain length plasticity (Bergkvist et al., 2012). Size selectivity grazing experiments in the Southern Ocean suggested that microzooplankton would preferentially graze on the nano- and pico-phytoplankton during the winter when the phytoplankton community was dominated by nano- and pico-cells (Froneman and Perissinotto, 1996). However, it has also been suggested that an increase of grazing on small phytoplankton may be caused by the growth of microzooplankton due to the artifact of removing 
https://doi.org/10.5194/bg-2021-226

Preprint. Discussion started: 1 September 2021

(c) Author(s) 2021. CC BY 4.0 License.

(c) (i)

345 mesozooplankton from the incubations (Schmoker et al., 2013; Calbet and Saiz, 2013). Meanwhile, this effect should be relatively small here since mesozooplankton was barely present in our $200-\mu \mathrm{m}$ screen during the one-year field study.

\section{Conclusion}

By statistically analyzing the relationships between plankton rates and environmental variables through a one-year period at a coastal station outside a eutrophic estuary, we explore the underlying mechanisms controlling the monthly change of phytoplankton growth and microzooplankton grazing. We find that the temporal change in environmental parameters including light, temperature, nitrate, and phosphate could have distinct impacts on the growth of different phytoplankton size classes. Also, the grazing mortalities of various phytoplankton size classes could be related to different factors, including salinity, phytoplankton standing stock, and ciliate abundance. Moreover, a selective grazing of microzooplankton on small cells may be important for maintaining high abundance of large chain-forming diatoms in this eutrophic system. In summary, our results suggested that both the bottom-up and the top-down factors can interact together to control the growth and grazing mortality of phytoplankton of various sizes.

Our one-year time-series study should offer valuable insights into the seasonal change and the interplay of various environmental factors in controlling plankton population dynamics in the ocean. In addition, our findings of seasonal patterns in plankton rates and their regulating mechanisms may be important for ocean biogeochemical modeling to accurately account for the carbon fluxes within the microbial food web and to better predict the shifts in the plankton community structure in response to future environmental and climate change.

\section{ASSOCIATED CONTENT}

AUTHOR INFORMATION

CORRESPONDING Author

Email: qianli@scsio.ac.cn

\section{ORCID}

Qian P Li: 0000-0002-9846-3243

\section{Present Address}

South China Sea Institute of Oceanology, 164 West Xingang Road, Guangzhou, China 510301

Data availability. Some of the data used in the present study are available in the Supplement. Other data analyzed in this article are tabulated herein. For any additional data please request from the corresponding author. 
https://doi.org/10.5194/bg-2021-226

Preprint. Discussion started: 1 September 2021

(c) Author(s) 2021. CC BY 4.0 License.

(c) (1)

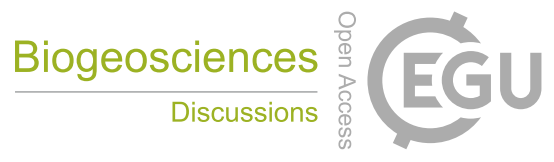

Author Contributions. YD conducted the investigation, methodology, Software and writing original draft. QPL provided supervision, visualization, investigation, conceptualization, methodology, data curation, reviewing and editing and funding acquisition. ZCW, YPS, ZJL, ZMG, ZZW and YCC helped investigation. All authors have given approval to the final version of the manuscript.\#

Competing interests. The authors declare no competing financial interest.

385 Acknowledgements. We would like to thank Mr. Guanghui Li for field assistance, as well as editor and reviewers for constructive comments.

Finanical support. This study was supported by the National Natural Science Foundation of China (41906132), the Guangdong Province Special Supporting Plan for Leading Talent (2019TX05H216), the Key Special Project for Introduced

Talents Team of Southern Marine Science and Engineering Guangdong Laboratory (Guangzhou) (GML2019ZD0305). 


\section{REFERENCES}

Anderson, S. R., and Harvey, E. L.: Seasonal variability and vrivers of microzooplankton grazing and phytoplankton growth in a subtropical estuary, Front. Mar. Sci., 6, 174, https://doi.org/10.3389/fmars.2019.00174, 2019.

Bergkvist, J., Thor, P., Jakobsen, H. H., Wängberg, S., and Selander, E.: Grazer-induced chain length plasticity reduces grazing risk in a marine diatom, Limnol. Oceanogr., 57, 318-324, https://doi.org/10.4319/1o.2012.57.1.0318, 2012.

Calbet, A., and Landry, M. R.: Phytoplankton growth, microzooplankton grazing, and carbon cycling in marine systems, Limnol. Oceanogr., 49, 51-57, https://doi.org/10.4319/lo.2004.49.1.0051, 2004.

Calbet, A., Trepat, I., Almeda, R., Saló, V., Saiz, E., Movilla, J. I., Alcaraz, A., Yebra, L., Simó, R.: Impact of microand nanograzers on phytoplankton assessed by standard and size-fractionated dilution grazing experiments, Aqua. Micro. Ecol., 50, 145-156, https://doi.org/10.3354/ame01171, 2008.

Calbet, A., and Saiz, E.: Effects of trophic cascades in dilution grazing experiments: from artificial saturated feeding responses to positive slopes, J. Plankton Res., 35, 1183-1191, https://doi.org/10.1093/plankt/fbt067, 2013.

Chen, B. Z., Liu, H. B., Landry, M. R., Chen, M. R., Sun, J., Shek, L., Chen, X., and Harrison. P. J.: Estuarine nutrient loading affects phytoplankton growth and microzooplankton grazing at two contrasting sites in Hong Kong coastal waters, Mar. Ecol. Prog. Ser., 379, 77-90, https://doi.org/10.3354/meps07888, 2009.

Chen, B. Z, Laws, E. A., Liu, H. B., and Huang, B. Q.: Estimating microzooplankton grazing half-saturation constants from dilution experiments with nonlinear feeding kinetics, Limnol. Oceanogr., 59, 639-644, https://doi.org/10.4319/lo.2014.59.3.0639, 2014.

Chen, M. R., Liu, H. B, Song, S. Q., and Sun, J.: Size-fractionated mesozooplankton biomass and grazing impact on phytoplankton in northern South China Sea during four seasons, Deep-Sea Res. II., 117, 108-118, https://doi.org/10.1016/j.dsr2.2015.02.026, 2015.

Christaki, U., Giannakourou, A., Wambeke, F. V., and Grégori, G.: Nanoflagellate predation on auto-and heterotrophic picoplankton in the oligotrophic Mediterranean Sea, J. Plankton Res., 23, 1297-1310, 415 https://doi.org/10.1093/plankt/23.11.1297, 2001.

Cloern, J. E., Foster, S. Q., and Kleckner, A.E.: Phytoplankton primary production in the world's stuarine-coastal ecosystem, Biogeosciences, 11, 2477e2501, https://doi.org/10.5194/bg-11-2477-2014, 2014.

Dong, Y., Li, Q. P., Liu, Z. J., Wu, Z. C., and Zhou, W. W.: Size-dependent phytoplankton growth and grazing in the northern South China Sea, Mar. Ecol. Prog. Ser., 599, 35-47, https://doi.org/10.3354/meps12614, 2018.

420 Eppley, R. W.: Temperature and phytoplankton growth in the sea, Fish. Bullet., 70(4), 1063-1086, 1972.

Froneman, P., and Perissinotto, R.: Microzooplankton grazing in the Southern Ocean: implications for the carbon cycle, Mar. Ecol., 17, 99-115, https://doi.org/10.1111/j.1439-0485.1996.tb00493.x, 1996. 
https://doi.org/10.5194/bg-2021-226

Preprint. Discussion started: 1 September 2021

(c) Author(s) 2021. CC BY 4.0 License.

(c) (i)

Franzè, G., Pierson, J. J., Stoecker D. K., and Lavrentyen, P. J.: Diatom-produced allelochemicals trigger trophic cascades in the planktonic food web, Limnol. Oceanogr., 63, 1093-1108, https://doi.org/10.1002/lno.10756, 2018.

Gan, J. P., Lu, Z. M., Dai, M. H., Cheung, A. Y. Y., Liu, H. B., and Harrison, Paul.: Biological response to intensified upwelling and to a river plume in the northeastern South China Sea: A modeling study, J. Geophys. Res., 115, C09001, https://doi.org/10.1029/2009JC005569, 2010.

Garrison, D. L., Gowing, M. M., Hughes, M. P., Campbell L., Caron D. A., Dennett, M. R., Shalapyonok, A., Olson, R. J., Landry, M. R., Brown, S. L., Liu, H. B., Azam, F., Steward, G. F., Ducklow, H. W., Smith, D. C.: Microbial food web structure in the Arabian Sea: a US JGOFS study, Deep-Sea Res. II., 47, 1387-1422, https://doi.org/10.1016/S09670645(99)00148-4, 2000.

Girault, M., Arakawa, H., and Hashihama, F.: Phosphorus stress of microphytoplankton community in the western subtropical North Pacific, J. Plankton Res., 35(1), 146-157, https://doi.org/10.1093/plankt/fbs076, 2013.

Guillard, R. R. L. and Kilham, P.: The ecology of marine plankton diatoms, in: The Biology of Diatoms, editd by: 435 Werner, D., University California Press, Berkeley, 372-469, 1977.

Hansen, H. P., and Koroleff. F.: Determination of dissolved inorganic phosphate, in: Methods of seawater analysis, edited by: Grasshoff, K., Kremling, K., and Ehrhardt, M., John Wiley and Sons. 159-228, https://doi.org/10.1002/9783527613984.ch10, 1999.

Haraguchi, L., Jakobse, H. H., Lundholm, N., and Carstensen, J.: Phytoplankton community dynamic: a driver for ciliate trophic strategies, Front. Mar. Sci., 5, 272, http://doi.org/10.3389/fmars.2018.00272, 2018.

Holling, C. S.: Some characteristics of simple types of predation and parasitism, The canadian entomologist, 91, 385$398,1959$.

Ichinotsuka, D., Ueno, H., and Nakano, S.: Relative importance of nanoflagellates and ciliates as consumers of bacteria in a coastal sea area dominated by oligotrichous Strombidium and Strobilidium, Aquat. Microb. Ecol., 42, 139-147, 445 https://doi.org/10.3354/ame042139, 2006.

Jolliff, J. K., Smith, T. A., Barron, C.N., deRada, S., Anderson, S. C., Gould, R. W., Arnone, R.: The impact of coastal phytoplankton blooms on ocean-atmosphere thermal energy exchange: Evidence from a two-way coupled numerical modeling system, Geophys. Res. Lett., 39, L24607, https://doi.org/10.1029/2012GL053634, 2012.

Kuhn, A. M., Fennel, K., and Mattern, J. P.: Model investigations of the North Atlantic spring bloom initiation, Prog. Oceanogr., 138, 176-193, https://doi.org/10.1016/j.pocean.2015.07.004, 2015.

Landry, M. R., and Hassett, R. P.: Estimating the grazing impact of marine micro-zooplankton, Mar. Biol., 67, 283288, https://doi.org/10.1007/bf00397668, 1982.

Landry, M. R., Monger, B. C., and Selph, K. E.: Time-dependency of microzooplankton grazing and phytoplankton growth in the subarctic Pacific, Prog. Oceanogr., 32, 205-222, https://doi.org/10.1016/0079-6611(93)90014-5, 1993. 
https://doi.org/10.5194/bg-2021-226

Preprint. Discussion started: 1 September 2021

(c) Author(s) 2021. CC BY 4.0 License.

\section{(c) (i)}

Landry, M. R., Ohman, M. D., Goericke, R., Stukel, M. R., and Tsyrklevich, K.: Lagrangian studies of phytoplankton growth and grazing relationships in a coastal upwelling ecosystem off Southern California, Prog. Oceanogr., 83, 208-216, https://doi.org/10.1016/j.pocean.2009.07.026, 2009.

Li, J., Plouchart, D., Zastepa, A. and Dittrich, M.: Picoplankton accumulate and recycle polyphosphate to support high primary productivity in coastal Lake Ontario, Sci. Rep., 9, 19563, https://doi.org/10.1038/s41598-019-56042-5, 2019.

Li, L., Lv, S.H., Jiang, T., Li. X.: Seasonal variation of size-fractionated phytoplankton in the Pearl River estuary, Chinese Sci. Bull., 58, 2303-2314, https://doi.org/10.1007/s11434-013-5823-1, 2013.

Li, Q. P., Franks, P. J. S. Landry M. R., Goericke R., and Taylor, A. G.: Modeling phytoplankton growth rates and chlorophyll to carbon ratios in California coastal and pelagic ecosystems, J. Geophys. Res., 115, G04003, https://doi.org/10.1029/2009JG001111, 2010.

Li, Q. P., Franks, P. J. S., Ohman, M. D., and Landry, M. R.: Enhanced nitrate fluxes and biological processes at a frontal zone in the southern California current system, J. Plankton Res., 34, 790-801, https://doi.org/10.1093/plankt/fbs006, 2012.

Li, Q. P., Zhou, W. W., Chen, Y. C., and Wu, Z. C.: Phytoplankton response to a plume front in the northern South China Sea, Biogeosciences, 15, 2551-2563, https://doi.org/10.5194/bg-15-2551-2018, 2018.

Lie, A. A. Y., and Wong, C. K.: Selectivity and grazing impact of microzooplankton on phytoplankton in two subtropical semi-enclosed bays with different chlorophyll concentrations, J. Exp. Mar. Biol. Ecol., 390(2), 149-159, http://doi.org/10.1016/j.jembe.2010.05.001, 2010.

Liu, K. K., Chao, S. Y., Shaw, P. T., Gong, G. C., Chen, C. C., and Tang, T. Y.: Monsoon-forced chlorophyll distribution and primary production in the South China Sea: observations and a numerical study, Deep Sea Res. I., 49, 1387475 1412, http://doi.org/10.1016/S0967-0637(02)00035-3, 2002.

Menden-Deuer, S., Lawrence, C., and Franzè, G.: Herbivorous protist growth and grazing rates at in situ and artificially elevated temperatures during an Arctic phytoplankton spring bloom, PeerJ, 6, e5264. https://doi.org/10.7717/peerj.5264, 2018.

Parsons, T. R, Maita, Y., and Lalli, C. M.: A Manual of Chemical and Biological Methods for Seawater Analysis, 480 Elsevier, New York, 1984.

Poulin, F. J., and Franks, P. J. S.: Size-structured planktonic ecosystems: constraints, controls and assembly instructions, J. Plankton Res., 32, 1121-1130, https://doi.org/10.1093/plankt/fbp145, 2010.

Rose, J. M., and Caron, D. A.: Does low temperature constrain the growth rates of heterotrophic protists? Evidence and implications for algal blooms in cold waters, Limnol. Oceanogr., 52, 886-895. https://doi.org/10.4319/10.2007.52.2.0886, 4852007.

Schmoker, C., Hernandez-Leon, S., and Calbet, A.: Microzooplankton grazing in the oceans: impacts, data variability, knowledge gaps and future directions, J. Plankton Res., 35, 691-706, https://doi.org/10.1093/plankt/fbt023, 2013. 
https://doi.org/10.5194/bg-2021-226

Preprint. Discussion started: 1 September 2021

(c) Author(s) 2021. CC BY 4.0 License.

(c) (i)

Staniewski, M. A., and Short, S. M.: Methodological review and meta-analysis of dilution assays for estimates of virus-and grazer-mediated phytoplankton mortality, Limnol. Oceanogr. Methods, 16, 649-668, https://doi.org/10.1002/lom3.10273, 2018.

Steinberg, D. K., and Landry, M. R.: Zooplankton and the ocean carbon cycle, Annu. Rev. Mar. Sci., 9, 413-444, https://doi.org/10.1146/annurev-marine-010814-015924, 2017.

Strom, S. L., Macri, E. L., and Olson, M. B.: Microzooplankton grazing in the coastal Gulf of Alaska: Variations in top-down control of phytoplankton, Limnol. Oceanogr., 52, 1480-94, https://doi.org/10.4319/lo.2007.52.4.1480, 2007.

Sun, J., Feng, Y., Zhou, F., Song, S., Jiang, Y., and Ding, C.: Top-down control of spring surface phytoplankton blooms by microzooplankton in the Central Yellow Sea, China, Deep-Sea Res., II, 97, 51-60, https://doi.org/10.1016/j.dsr2.2013.05.005, 2013.

Unrein, F., Massana, R., Alonso-Sáez, L., and Gasol, J. M.: Significant year-round effect of small mixotrophic flagellates on bacterioplankton in an oligotrophic coastal system, Limnol. Oceanogr., 52(1), 456-469, https://doi.org/10.4319/lo.2007.52.1.0456, 2007.

Utermöhl, H.: Zur vervolkomnung der quantitative Phytoplankton-Methodik. Mitteillung Internationale Verhandlungen Limnologie, 9, 1-38, https://doi.org/10.1080/05384680.1958.11904091, 1958.

Wang, W. C., Sun, S., Sun, X. X., Zhang, G. T., and Zhang, F.: Spatial patterns of zooplankton size structure in relation to environmental factors in Jiaozhou Bay, South Yellow Sea, Mar. Pollut. Bull., 150, 110698, 505 https://doi.org/10.1016/j.marpolbul.2019.110698, 2020.

Worden, A. Z., Nolan, J. K., and Palenik B.: Assessing the dynamics and ecology of marine picophytoplankton : The importance of the eukaryotic component, Limnol. Oceanogr., 49(1), 168-179, https://doi.org/10.4319/lo.2004.49.1.0168, 2004.

Wu, Z. C., and Li, Q. P. Spatial distributions of polyunsaturated aldehydes and their biogeochemical implications in 510 the Pearl River Estuary and the adjacent northern South China Sea, Prog. Oceanogr., 147, 1-9, https://doi.org/10.1016/j.pocean.2016.07.010, 2016.

Zhou, W. W., Li, Q. P., and Wu, Z. C. Coastal phytoplankton responses to atmospheric deposition during summer, Limnol. Oceanogr., 66(4), 1298-1315, https://doi.org/10.1002/lno.11683, 2021.

Zöllner, E., Hoppe, H., Sommer, U., and Jürgens, K.: Effect of zooplankton-mediated trophic cascades on marine 515 microbial food web components (bacteria, nanoflagellates, ciliates), Limnol. Oceanogr., 54(1), 262-275, https://doi.org/10.4319/lo.2009.54.1.0262, 2009. 
https://doi.org/10.5194/bg-2021-226

Preprint. Discussion started: 1 September 2021

(c) Author(s) 2021. CC BY 4.0 License.

(c) (i)

\section{Figures and Legends}

Figure 1: Geographic map of the Pearl River Estuary and the adjacent northern South China Sea. The filled star in the enlarged panel is the monthly timesieris station $\left(21.9^{\circ} \mathrm{N}, 113.8^{\circ} \mathrm{E}\right)$ near Wanshan Island from June 2018 to June 2019.

Figure 2: Temporal variations of (A) temperature, salinity, (B) flow rate, solar radiation, (C) nitrate, silicate, phosphorus, and N/P ratio of the surface water at the Wanshan station from June 2018 to June 2019. Error bars are standard deviations.

Figure 3: Temporal change of (A) size-fractionated chlorophyll- $a$ concentrations of micro-, nano-, and pico-phytoplankton as well as (B) the total chlorophyll- $a$ concentration and the size-fractionated percentages at the Wanshan station from June 2018 to June 2019. Error bars are standard deviations.

530 Figure 4: Temporal changes of (A) diatom abundance, (B) Synechococcus and pico-eukaryotes abundances, total picophytoplankton biomass, and $(\mathrm{C})$ ciliate abundance and the ciliate-to-chlorophyll ratio of the surface water at the Wanshan station from June 2018 to June 2019. Error bars are standard deviations.

Figure 5: Temporal variations of (A) natural phytoplankton growth rate $\left(\mu_{0}\right),(\mathrm{B})$ microzooplankton grazing rate $(m)$, and $(\mathrm{C})$ 535 nutrient enriched phytoplankton growth rate $\left(\mu_{\mathrm{n}}\right)$, as well as their size-fractionated components for micro-, nano-, and picocells at the Wanshan station from June 2018 to June 2019. Error bars are standard deviations.

Figure 6: Redundancy analyses (RDA) representing (A) the relationships of the size-fractionated phytoplankton growth rates $\left(\mu_{\text {micro, }} \mu_{\text {nano, }}\right.$ and $\left.\mu_{\text {pico }}\right)$ with various environmental variables and (B) the relationships of the size-fractionated microzooplankton grazing rates $\left(m_{\text {micro }}, m_{\text {nano }}\right.$, and $\left.m_{\text {pico}}\right)$ with various environmental variables. Red arrows are environmental variables with blue arrows for rates; $C h l_{\mathrm{m}}, C h l_{\mathrm{n}}$, and $C h l_{\mathrm{p}}$ are the chlorophyll- $a$ concentrations of micro-, nano-, and picophytoplankton; $C_{\text {pico }}$ is the picophytoplankton carbon biomass with Peuk for the picoeukaryote and Syne for the Synechococcus.

545 Figure 7: Regressions between phytoplankton growth rate and microzooplankton grazing rate for micro-, nano-, and picocells in the coastal NSCS outside PRE. Note that negative rates have been excluded from the regression. 


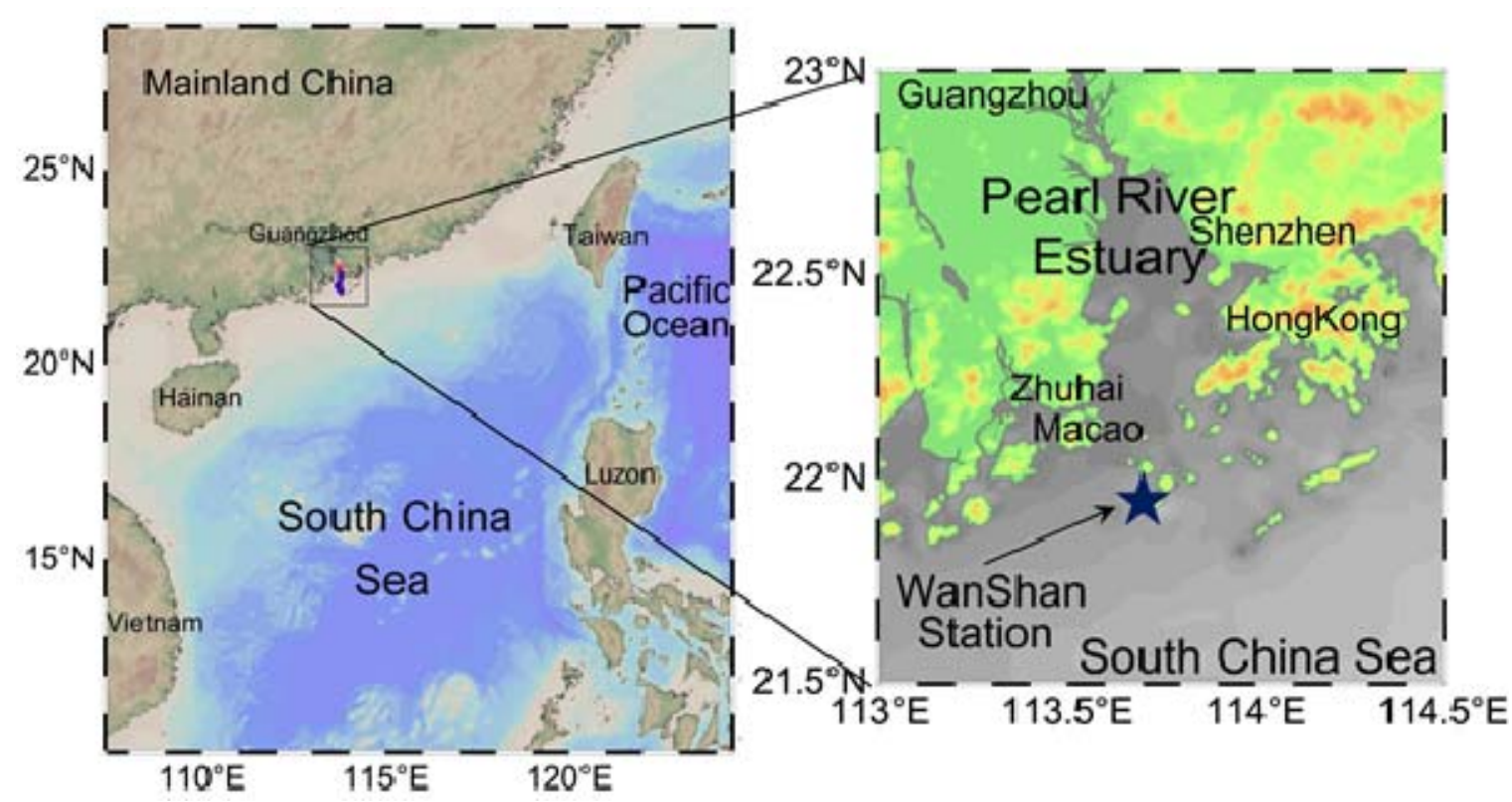

Figure 1: Geographic map of the Pearl River Estuary and the adjacent northern South China Sea. The filled star in the enlarged panel is the monthly timesieris station $\left(21.9^{\circ} \mathrm{N}, 113.8^{\circ} \mathrm{E}\right)$ near Wanshan Island from June 2018 to June 2019. 

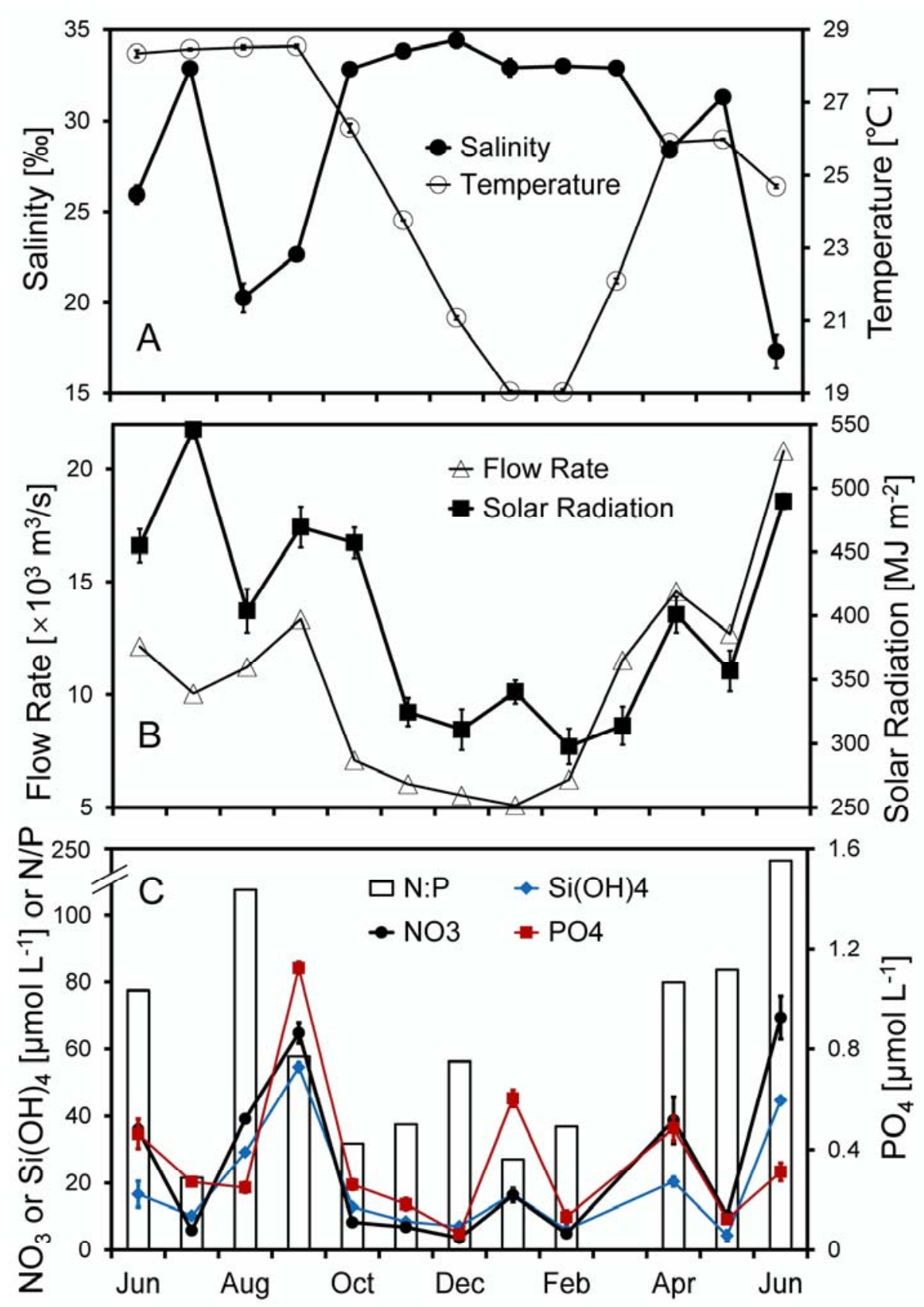

Figure 2: Temporal variations of (A) temperature, salinity, (B) flow rate, solar radiation, (C) nitrate, silicate, phosphorus, and N/P ratio of the surface water at the Wanshan station from June 2018 to June 2019. Error bars are standard deviations. 


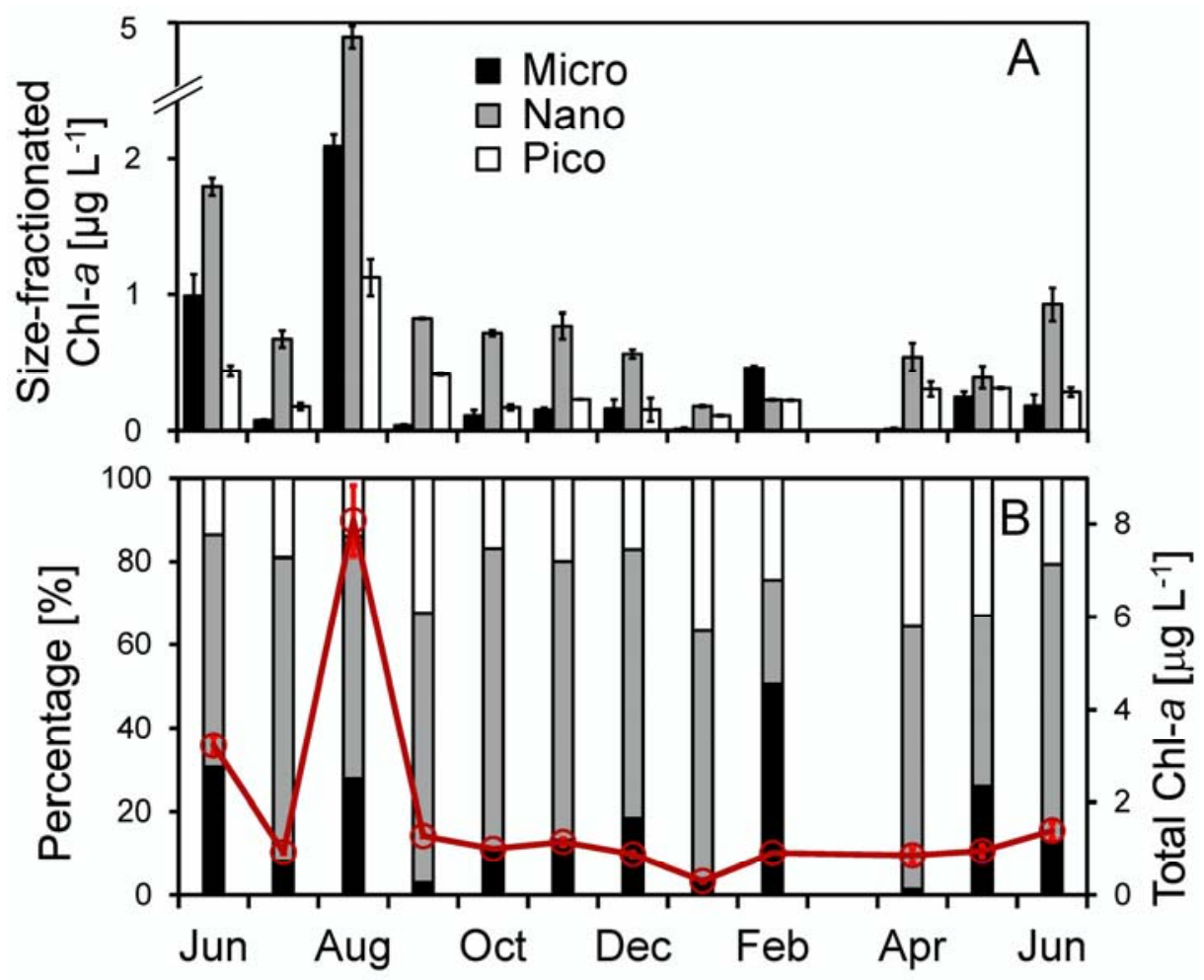

560 Figure 3: Temporal change of (A) size-fractionated chlorophyll- $a$ concentrations of micro-, nano-, and pico-phytoplankton as well as (B) the total chlorophyll- $a$ concentration and the size-fractionated percentages at the Wanshan station from June 2018 to June 2019. Error bars are standard deviations. 

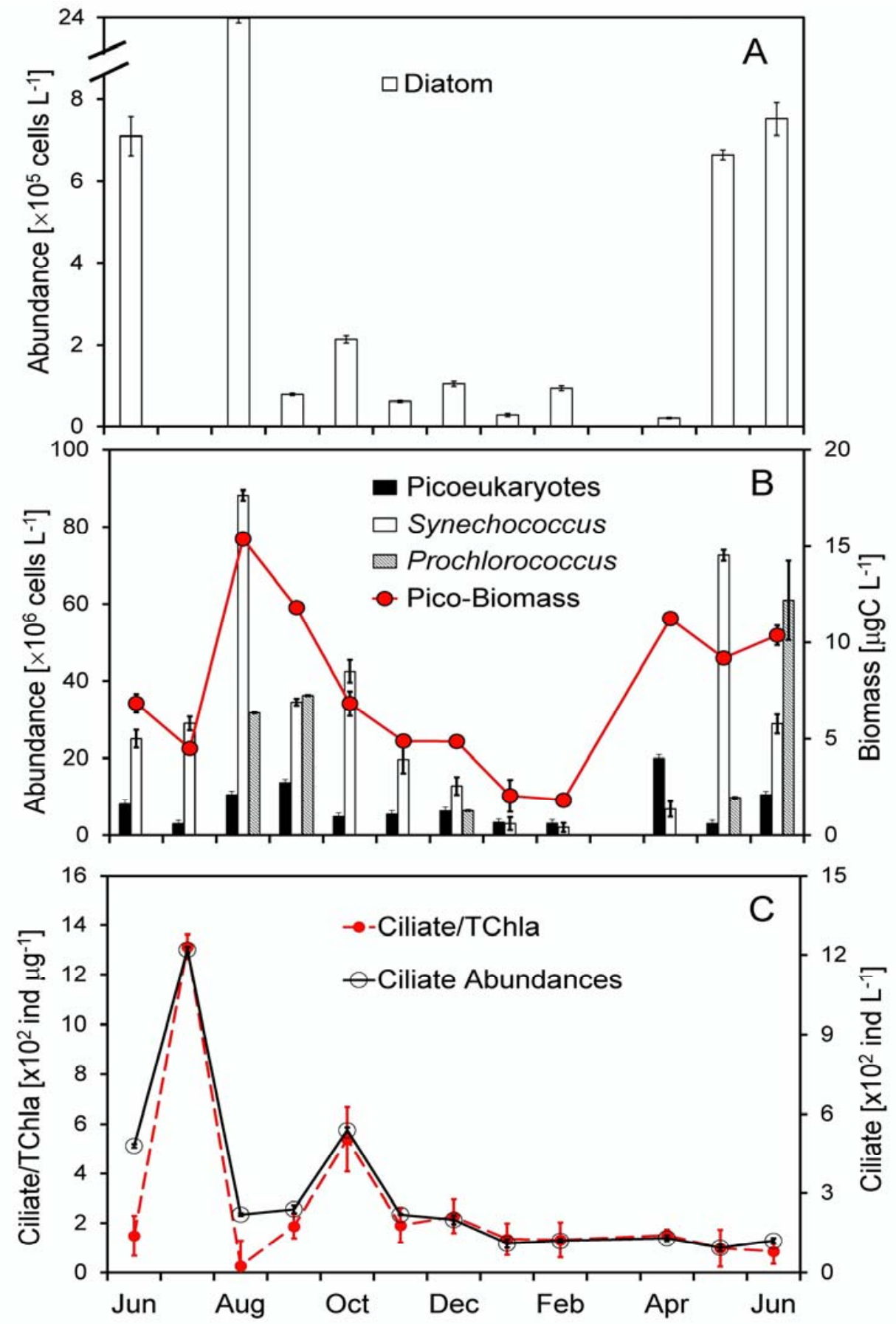

Figure 4: Temporal changes of (A) diatom abundance, (B) Synechococcus and pico-eukaryotes abundances, total picophytoplankton biomass, and (C) ciliate abundance and the ciliate-to-chlorophyll ratio of the surface water at the Wanshan station from June 2018 to June 2019. Error bars are standard deviations. 
https://doi.org/10.5194/bg-2021-226

Preprint. Discussion started: 1 September 2021

(c) Author(s) 2021. CC BY 4.0 License.
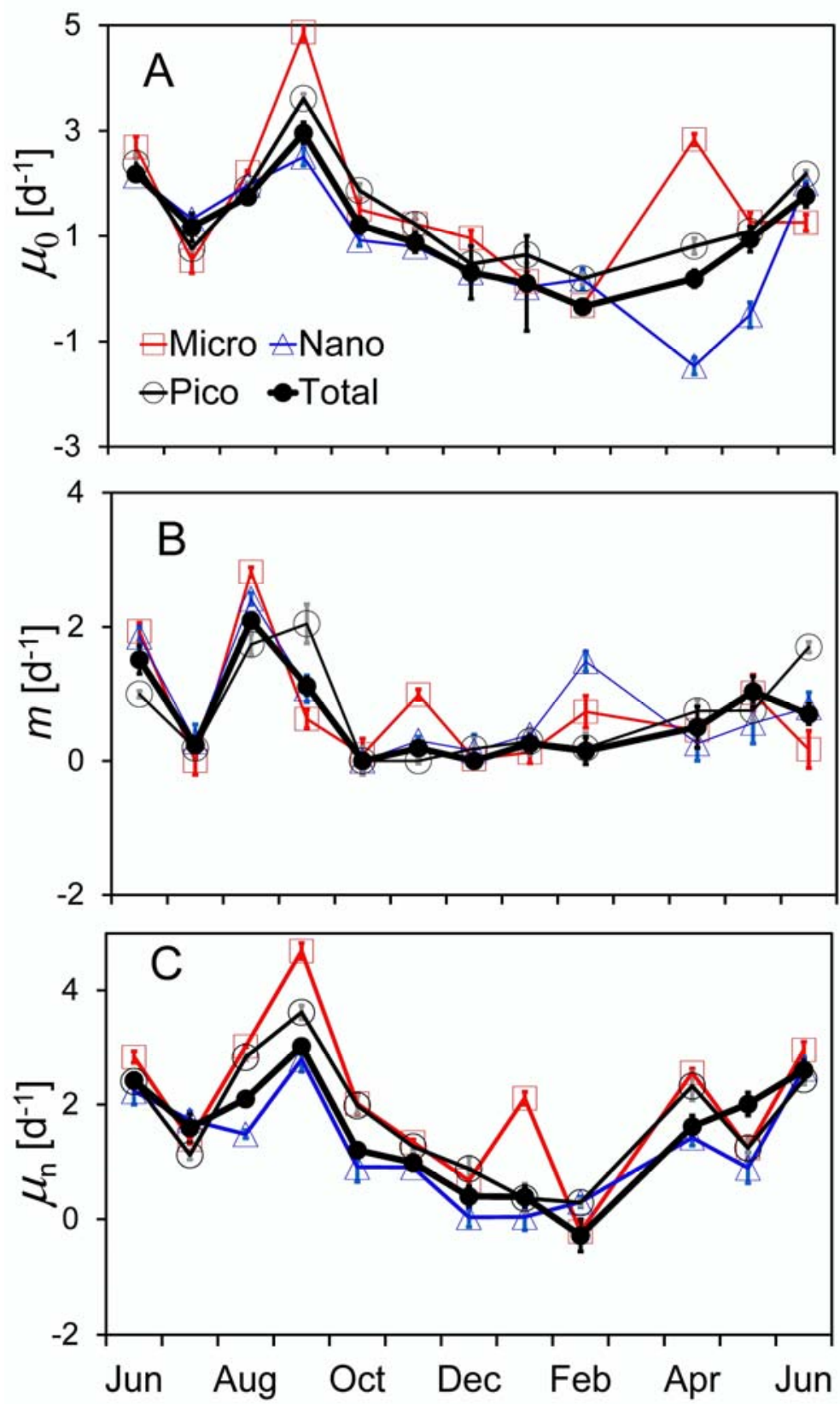

Figure 5: Temporal variations of (A) natural phytoplankton growth rate $\left(\mu_{0}\right),(\mathrm{B})$ microzooplankton grazing rate $(\mathrm{m})$, and $(\mathrm{C})$ nutrient enriched phytoplankton growth rate $\left(\mu_{\mathrm{n}}\right)$, as well as their size-fractionated components for micro-, nano-, and picocells at the Wanshan station from June 2018 to June 2019. Error bars are standard deviations. 

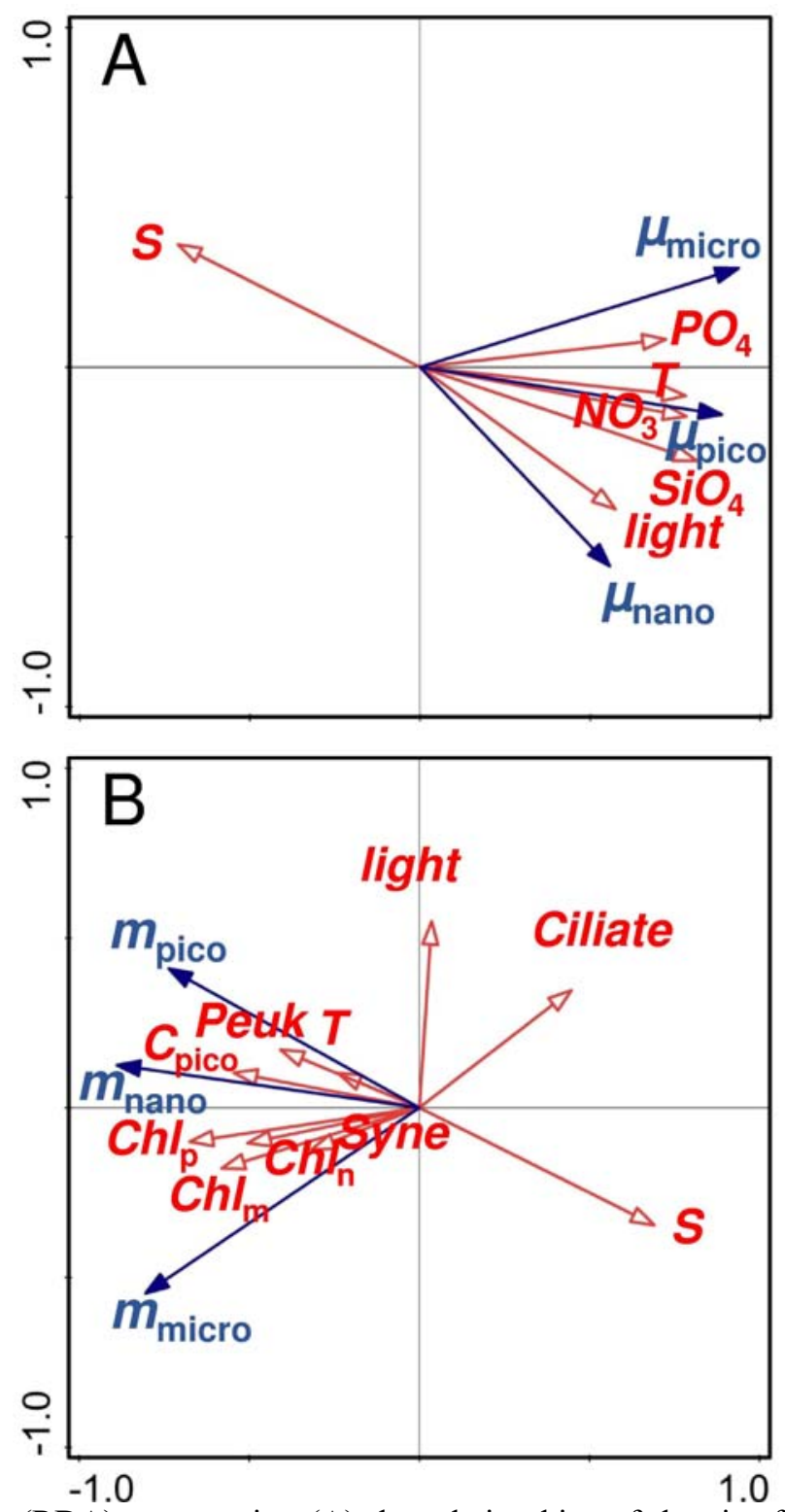

Figure 6: Redundancy analyses $(\mathrm{RDA})$ representing $(\mathrm{A})$ the relationships of the size-fractionated phytoplankton growth rates $\left(\mu_{\text {micro }}, \mu_{\text {nano }}\right.$, and $\left.\mu_{\text {pico }}\right)$ with various environmental variables and (B) the relationships of the size-fractionated microzooplankton grazing rates $\left(m_{\text {micro }}, m_{\text {nano, }}\right.$, and $\left.m_{\text {pico }}\right)$ with various environmental variables. Red arrows are environmental variables with blue arrows for rates; $C h l_{\mathrm{m}}, C h l_{\mathrm{n}}$, and $C h l_{\mathrm{p}}$ are the chlorophyll- $a$ concentrations of micro-, nano-, and picophytoplankton; $C_{\text {pico }}$ is the picophytoplankton carbon biomass with Peuk for the picoeukaryote and Syne for the Synechococcus. 
https://doi.org/10.5194/bg-2021-226

Preprint. Discussion started: 1 September 2021

(c) Author(s) 2021. CC BY 4.0 License.

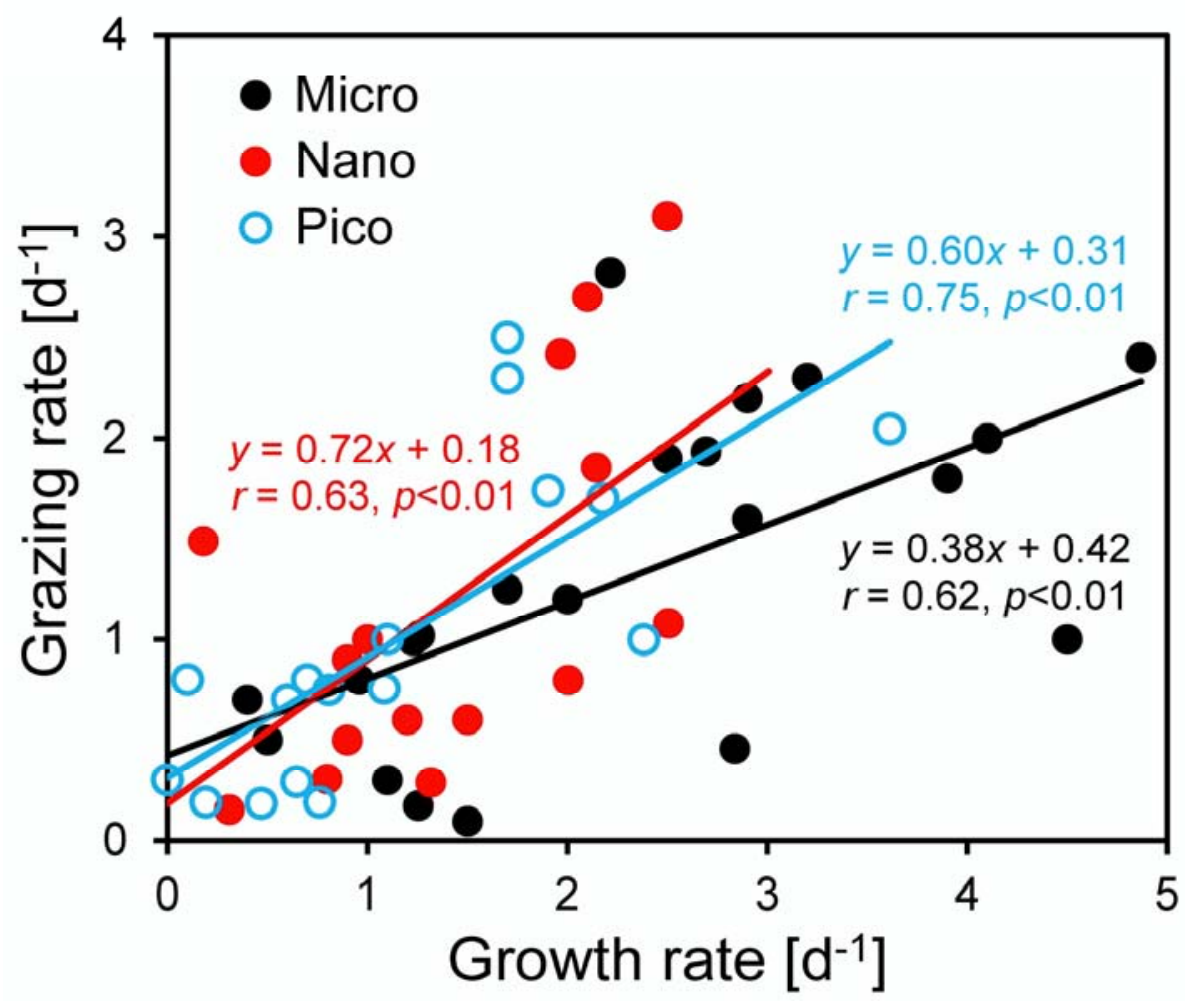

Figure 7: Regressions between phytoplankton growth rate and microzooplankton grazing rate for micro-, nano-, and picocells in the coastal NSCS outside PRE. Note that negative rates have been excluded from the regression. 